OUTBREAK CULTURE 



\title{
OUTBREAK CULTURE
}

The Ebola Crisis and the Next Epidemic With a New Preface and Epilogue

\section{PARDIS SABETI and LARA SALAHI}

\author{
III \\ Harvard University Press \\ Cambridge, Massachusetts | London, England
}


Copyright $\odot 2018$ by the President and Fellows of Harvard College

New Preface and Epilogue copyright (c) 2021 by the

President and Fellows of Harvard College

All rights reserved

Printed in the United States of America

First Harvard University Press hardcover edition, 2018

First Harvard University Press paperback edition, 2021

First printing

Cover design: Tim Jones

9780674269736 (EPUB)

9780674269750 (PDF)

Library of Congress Cataloging-in-Publication Data

is available from loc.gov

ISBN 9780674260474 (pbk.) 
THIS BOOK IS DEDICATED TO

Our families, for their support

Our colleagues, for their collaboration

All who are working to improve the culture of global emergency response

Dr. Sheik Humarr Khan, for all that he gave and all that we learned 
